\title{
Effects of Various Doses of Cholecystokinin Octapeptide and Cerulein on Antral Slow-Wave Frequency and Amplitude in Conscious Sheep
}

\author{
K.W. ROMAŃSKI \\ Department of Animal Physiology, Veterinary School, Wrocław University of Environmental \\ and Life Sciences, Wrocław, Poland \\ Received November 2, 2006 \\ Accepted July 7, 2008
}

\begin{abstract}
Romański K.W: Effects of Various Doses of Cholecystokinin Octapeptide and Cerulein on Antral Slow-Wave Frequency and Amplitude in Conscious Sheep. Acta Vet. Brno 2008, 77: 489-501.

It is suspected that cholecystokinin (CCK) might affect antral slow-wave frequency and amplitude, but in sheep this problem is virtually unknown. Therefore the myoelectric activity was continuously recorded before and after intravenous administration of $0.15 \mathrm{M} \mathrm{NaCl}$ or CCK peptides in adult rams, equipped with platinum bipolar electrodes in the abomasal antrum, duodenum, and jejunum. CCK octapeptide (CCK-OP) was given to five rams at doses of $17.5,175$, or $1750 \mathrm{pmol} /$ $\mathrm{kg}$ and cerulein was administered to six rams at doses of $0.735,7.35$, or $73.5 \mathrm{pmol} / \mathrm{kg}$ of body weight. Each dose was infused to fasted or non-fasted animals for 30,60, 120, or $300 \mathrm{~s}$ during phase $1,2 \mathrm{a}$ or $2 \mathrm{~b}$ (the less or more intense) of the migrating myoelectric complex (MMC). The 300 -sec infusion of the moderate CCK-OP dose during the less intense or more intense phase $2 \mathrm{~b}$ of the MMC increased the antral slow-wave amplitude from $79 \pm 7$ to $124 \pm 26 \mu \mathrm{V}(p<0.01)$ and from $82 \pm 8$ to $175 \pm 40 \mu \mathrm{V}(p<0.001)$, respectively. The $300-\mathrm{sec}$ infusion of the highest CCK-OP dose under the same conditions increased antral slow-wave amplitude from $79 \pm 6$ to $121 \pm 24 \mu \mathrm{V}$ $(p<0.05)$ and from $84 \pm 9$ to $138 \pm 27 \mu \mathrm{V}(p<0.01)$, respectively.

Administration of the moderate dose of CCK for $120 \mathrm{~s}$ in the course of the less or more intense phase $2 \mathrm{~b}$ of the MMC increased antral slow-wave frequency from $6.1 \pm 0.2$ to $6.6 \pm 0.4 \mathrm{cpm}$ (N.S.) and from $6.1 \pm 0.3$ to $6.8 \pm 0.4 \mathrm{cpm}(p<0.05)$, respectively. Administration of the highest dose of CCK-OP for $120 \mathrm{~s}$ in the course of the less or more intense phase $2 \mathrm{~b}$ of the MMC increased the antral slow-wave frequency from $6.2 \pm 0.3$ to $7.2 \pm 0.4(p<0.05)$ and from $6.0 \pm 0.3$ to 7.8 $\pm 0.6 \mathrm{cpm}(p<0.001)$, respectively. It is concluded that CCK in physiological and putatively pharmacological doses can affect the slow-wave frequency and amplitude in sheep related in part to the small-intestinal MMC phase and the intensity of the antral motor activity.
\end{abstract}

Sheep, abomasal antrum, myoelectric activity, slow-wave frequency and amplitude

It is well established that cholecystokinin (CCK) is one of the most important gut hormones, exerting multiple effects on gastrointestinal motility (Grider 1994). In monogastrics, CCK is known to switch the interdigestive motility pattern to the digestive pattern, stimulate pyloric motility, and also to inhibit gastric motility and emptying (Grider 1994; Thomas et al. 1979; Thor et al. 1988). However, when the hormone was given intra-arterially to anaesthetized animals or when its motor effect on the stomach was studied in vitro, the effect on the gastric motor activity was stimulatory (Kuwahara et al. 1986; Morgan et al. 1978). A close derivative of CCK, amphibian cerulein, is active in mammals as well and exerts similar effects on gastrointestinal motility (Ogawa and Tanaka 1992; Scarpignato et al. 1993). Thus the role of CCK in the control of gastric motility in non-ruminant species is not fully established. In ruminants, endogenous CCK exerts its regulatory functions and its effect on gastric motor activity is inhibitory (McLeay and Bell 1980; Ruckebusch 1988; Tachibana et al. 1995). Both CCK-octapeptide (CCK-OP), which is the form of CCK present in sheep, and cerulein are used in motility studies (Titchen 1986; Romański 2004a). These actions of CCK are mediated by specific receptors expressed

Phone: +48713205422

Fax: + 48713211567

E-mail: romanski@ozi.ar.wroc.pl,krzysztof.romanski@up.wroc.pl http://www.vfu.cz/acta-vet/actavet.htm 
by gastrointestinal smooth muscles and by central and peripheral neurons (Noble et al. 1999). As CCK receptors are also present on the interstitial cells of Cajal (Patterson et al. 2001), it might be expected that CCK may affect the antral slow-wave frequency and amplitude. It has been reported that the motor effects of CCK also comprise an increase in slow-wave frequency (Ohkawa and Watanabe 1977). However, as this effect was not always observed in monogastric species (Chen et al. 1995), the role of CCK in the control of gastric slow waves remains uncertain. No information is available regarding the effect of CCK on antral slow waves in ruminants. In a preliminary study in sheep, CCK-OP and cerulein seemed to affect antral slow waves. Thus the objective of this study was to assess the precise effect of various doses of CCK-OP and cerulein administered over different periods of time and during various phases of the migrating myoelectric complex (MMC) on antral slow-wave frequency and amplitude in fasted and non-fasted conscious sheep.

\section{Materials and Methods}

\section{Animal preparation}

Six healthy rams of the Polish Merino breed weighing $38-44 \mathrm{~kg}$ each were used. Before the surgery the rams were fed regularly according to the standard procedure (see Romański 2004b) and were adapted for the experiments for at least two weeks. This study was performed in accordance with the relevant allowance number of animals with regard to animal welfare and approval of the whole experimental protocol by the local Ethics Committee (87/03) in Wroclaw. In 24-h fasted animals, right lateral laparotomy was performed under general and local anaesthesia and a bipolar platinum electrode was sutured to the right lateral surface of the pyloric antrum, $4 \mathrm{~cm}$ from the pylorus, on the serosal side. For a reliable recognition of the MMC and identification of its phases, four additional electrodes were attached to the small intestinal wall. These electrodes were located as follows: on the duodenal bulb $6 \mathrm{~cm}$ distally to the pylorus, on the duodenum $50 \mathrm{~cm}$ distally from the bulbar electrode, on the jejunum $200 \mathrm{~cm}$ distally from the duodenal electrode, and on the jejunum $100 \mathrm{~cm}$ distally from the first jejunal electrode. Only rams exhibiting normal myoelectric activity after the postoperative recovery period were included in the study. Other details of animal preparation were similar to those described earlier (Romański 2004a).

Experimental protocol

A total of 484 experiments lasting 3-4 h each were performed. Continuous myoelectrical recordings were performed in the conscious rams using a multichannel electroencephalograph (Reega Duplex TR XVI, Alvar, Montreuil, France). Before the experiments (performed in non-fasted animals) the rams received standard food for the last time the day before the experiment; fodder was available from midday of that day. The second set of experiments was performed in $40-42 \mathrm{~h}$ fasted rams. Each experiment comprised two main parts. Initially, at least two consecutive phases 3 of the MMC were recorded (the so-called "own control"). Then, in the course of the control experiments, $5 \mathrm{ml}$ of $0.15 \mathrm{M} \mathrm{NaCl}$ were injected over $30 \mathrm{~s}$ into the jugular vein through a thin polyethylene catheter introduced before the experiment and at least one full $\mathrm{MMC}$ cycle was recorded. During the remaining experiments, after recording the "own control" part, random injections of CCK-OP (Sincalide, Squibb Inst., Princeton, USA) at doses of $17.5,175$, or $1750 \mathrm{pmol} / \mathrm{kg}$ and cerulein (Farmitalia Carlo Erba, Milan, Italy) at doses of $0.735,7.37$ or $73.5 \mathrm{pmol} / \mathrm{kg}$ of body weight were given. Each dose (the lowest, moderate and highest) of the hormonal peptide was administered over $30,60,120$, or $300 \mathrm{~s}$ through the indwelling jugular catheter. In nonfasted rams, either hormonal peptide was randomly injected during phase $1,2 \mathrm{a}$, or $2 \mathrm{~b}$ of the MMC, identified in the duodenum, about 10 min after the initiation of the given MMC phase. During this time the antrum exhibited an interrupted spiking activity. The experiments with hormonal peptide administration during phase $2 \mathrm{~b}$ of the MMC were further differentiated depending on its intensity. After hormone administration the recording was continued until the arrival of phase 3 of the MMC. Calibrations of the myoelectric recording were performed thoroughly. Similar experimental protocols were designed in previous studies (Romański 2002, 2004a, 2005a), where other details of the whole procedure can be found.

\section{Calculations}

The MMC cycles were identified in the small intestine and their phases were recognized mostly in the duodenum according to the criteria of Code and Marlett (1975). Furthermore, phase 2 of the MMC was subdivided into phase $2 \mathrm{a}$ and $2 \mathrm{~b}$ according to the suggestion of Dent et al. (1983). A less (weak) and more (strong) intense phase $2 \mathrm{~b}$ was also distinguished. Phase $2 \mathrm{~b}$ of the MMC was considered weak when the contribution of slow waves with spike bursts in the duodenum during this phase was $20 \%$ or less. Spike bursts of amplitude below $20 \mu \mathrm{V}$ and duration below $0.5 \mathrm{~s}$ were omitted. Antral slow-wave frequency and amplitude were calculated in 1-2 minute control periods and for ten minutes following the injection of the hormonal peptides. These data are expressed in cycles per minute $(\mathrm{cpm})$ and $\mu \mathrm{V}$, respectively. Their accuracies were about $0.1 \mathrm{cpm}$ and about $5 \mu \mathrm{V}$. Control antral slow-wave frequencies are presented as averages for two-minute control periods. Increased slow-wave frequencies after CCK peptide administration are presented as the average data for a period lasting $30 \mathrm{~s}$ or more starting no earlier than immediately after the termination of hormone injection and no later than 1 min afterwards 
(first or primary response). The durations of these periods are presented separately. To demonstrate the subsequent inhibitory response (second or secondary response), the durations of the inhibitory periods were measured and the average values of the slow-wave frequency during these periods are depicted. Control slow-wave amplitudes were measured for $1 \mathrm{~min}$ just before hormonal peptide administration. The increased slow-wave amplitudes (inhibitory secondary responses were not observed here) are presented as average amplitudes of one-minute periods directly following the beginning of hormone administration. The overall duration of these responses, expressed in seconds (s) is presented separately.

The data were statistically evaluated and the mean values with standard deviations were calculated and presented. Statistical significances between the control data and data obtained in response to hormonal peptide administration were calculated using Student's $t$-test for paired values preceded by one-way analysis of variance (Snedecor and Cochran 1971).

\section{Results}

\section{Control experiments}

During the control experiments performed in fasted and non-fasted animals, the injection of saline evoked alterations neither in the antral slow-wave frequency nor the amplitude compared with the relevant data obtained from the control experiments with hormone administration (data not shown). All the values of the antral slow-wave frequency and amplitude (but not the duration) were compared with the "own control" data.

Effects of the lowest dose of CCK peptides upon the antral slow-wave frequency in non-fasted sheep

Administration of the lowest doses of CCK-OP or cerulein evoked significant changes neither in antral slow-wave frequency nor the amplitude compared with the relevant control values; these data are therefore omitted.

Effects of the moderate and the highest doses of CCK-OP on the antral slowwave frequency in non-fasted sheep

Slow injection of the moderate or highest dose of CCK-OP initially evoked a significant increase in the antral slow-wave frequency, these changes in response to the highest dose of CCK-OP were more pronounced (Fig. 1). The duration of hormone injection was also important. The weakest effect was observed when the hormone was administered during phase $2 \mathrm{a}$ of the MMC. After the enhancement period of the slow wave frequency, its periodical suppression was observed (Fig. 1). The durations of the stimulatory changes were directly proportional to the dose of the hormone and the duration of hormone administration (Table 1). Accordingly, the longest period during which the slow-wave frequency values were elevated was observed after the highest dose of CCK-OP administered in the course of

Table 1. The durations of periods (in seconds) in which the antral slow-wave frequency was altered in response to the moderate and highest dose of CCK-OP, administered in non-fasted sheep during the various phases of the migrating myoelectric complex (MMC)

\begin{tabular}{|c|c|c|c|c|c|c|c|c|}
\hline & \multicolumn{4}{|c|}{$\begin{array}{c}\text { CCK-OP 175 pmol/kg } \\
\text { MMC phase: }\end{array}$} & \multicolumn{4}{c|}{$\begin{array}{c}\text { CCK-OP 1750 pmol/kg } \\
\text { MMC phase: }\end{array}$} \\
\hline & 1 & $2 \mathrm{a}$ & $2 \mathrm{~b}(\mathrm{w})$ & $2 \mathrm{~b}(\mathrm{~s})$ & 1 & $2 \mathrm{a}$ & $2 \mathrm{~b}(\mathrm{w})$ & $2 \mathrm{~b}(\mathrm{~s})$ \\
\hline 30 s mean & 441 & 68 & 768 & 514 & 1126 & 426 & 1638 & 1862 \\
\pm S.D. & 182 & 29 & 312 & 286 & 584 & 153 & 721 & 819 \\
\hline 60 s mean & 259 & 36 & 435 & 341 & 568 & 227 & 845 & 927 \\
\pm S.D. & 113 & 17 & 176 & 128 & 287 & 78 & 301 & 368 \\
\hline 120 s mean & $108^{\mathrm{c}}$ & - & $218^{\mathrm{c}}$ & 186 & $365^{\mathrm{c}}$ & $87^{\mathrm{c}}$ & $88^{\mathrm{c}}$ & $586^{\mathrm{c}}$ \\
\pm S.D. & 36 & & 74 & 69 & 124 & 30 & 36 & 240 \\
\hline 300 s mean & $44^{\mathrm{c}}$ & - & $126^{\mathrm{c}}$ & $94^{\mathrm{c}}$ & $153^{\mathrm{c}}$ & $42^{\mathrm{c}}$ & $69^{\mathrm{c}}$ & $224^{\mathrm{c}}$ \\
\pm S.D. & 16 & & 53 & 31 & 71 & 14 & 28 & 112 \\
\hline
\end{tabular}

Explanations: $2 b(w)$ - weak phase 2b MMC; $2 b(s)$ - strong phase $2 b$ MMC; $30 \mathrm{~s}, 60 \mathrm{~s}, 120 \mathrm{~s}, 300 \mathrm{~s}-$ the duration of hormone injections in seconds. Statistical significances vs. relevant $30 \mathrm{~s}$ value: ${ }^{\mathrm{a}} p<0.05,{ }^{\mathrm{b}} p<0.01,{ }^{\mathrm{c}} p<0.001$, $\mathrm{n}=5$, Student's $t$-test for paired values preceded by ANOVA I 

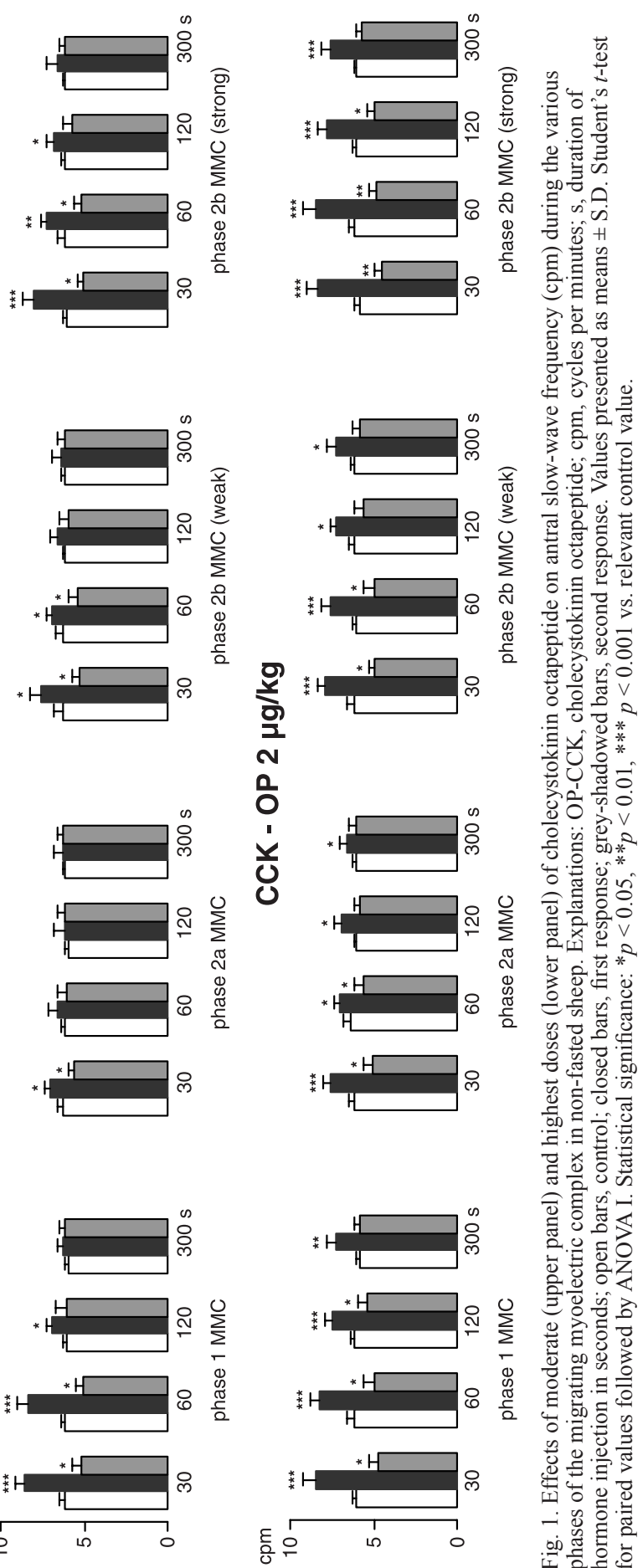

phase $2 b$ of the MMC (Table 1). The stimulatory effect of CCK-OP on the antral slowwave frequency was followed by its transient decrease (Fig. 1). Although the first response to $\mathrm{CCK}-\mathrm{OP}$ administration was stimulatory, the second response exhibited an inhibitory character. Significant inhibition of the antral slow-wave frequency was observed after the moderate and highest dose of CCK-OP given over 30-120 $\mathrm{S}$ in the course of phases 1 , $2 \mathrm{a}$, and weak phase $2 \mathrm{~b}$ of the MMC (Fig. 1). The duration of the post-stimulatory (inhibitory) period following CCK-OP administration regarding the antral slowwave frequency is not shown. However, in nonfasted sheep the highest dose of CCK-OP administered for 120 and $300 \mathrm{~s}$ in the course of strong phase $2 \mathrm{~b}$ of the MMC caused significantly longer inhibition than after CCK-OP given for $30 \mathrm{~s}$.

Effects of the moderate and highest doses of cerulein on the antral slow-wave frequency in non-fasted sheep

Injections of the moderate and highest doses of cerulein exerted effects which were mostly comparable to those evoked by CCK-OP. However, administration of the moderate dose of cerulein was efficient only when the hormonal peptide was given for 30 or 60 $\mathrm{s}$ during phase $2 \mathrm{~b}$ of the $\mathrm{MMC}$ (Fig. 2). The injection of the highest dose of cerulein also produced a smaller increase in slow-wave frequency 

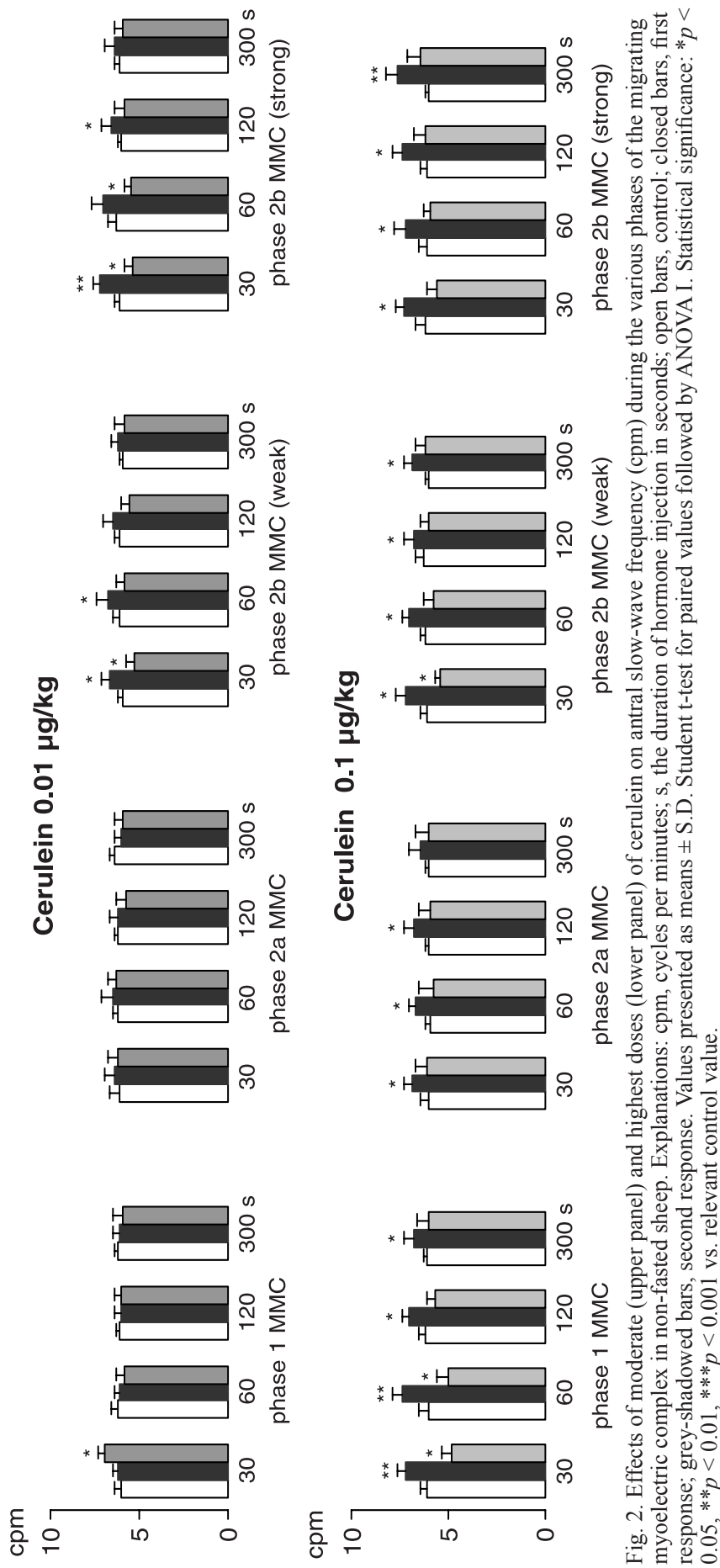

than the highest dose of CCK-OP. The relationship between the dose and time of administration of cerulein and its effect on the antral slow-wave frequency was roughly similar to that of CCK-OP administration. The duration of the stimulatory effect of cerulein on slow-wave frequency was clearly dosedependent and was highest when the hormonal peptide was given during phase $2 b$ of the MMC (Table 2). During the longest cerulein administration, the duration of the response was the shortest. Significant changes were observed in response to the moderate and highest dose of cerulein given for $30-60 \mathrm{~s}$ in the course of phase 1 and $2 \mathrm{~b}$ of the MMC (Fig. 2). The duration of the post-stimulatory (inhibitory) periods following cerulein administration regarding the antral slow-wave frequency are not shown. However, in non-fasted sheep the highest dose of CCK-OP administered for $120 \mathrm{~s}$ in the course of phase 1 of the MMC caused significantly longer inhibition than cerulein given for $30 \mathrm{~s}$.

Effects of the moderate and highest doses of CCK-OP on the antral slow-wave amplitude in non-fasted sheep

The influence of CCKOP administration on the antral slow-wave amplitude was substantial. The stimulatory effect of the moderate dose of the hormone was stronger than 
Table 2. The durations of periods (in seconds) in which the antral slow wave frequency was altered in response to the moderate and highest dose of cerulein, administered in non-fasted sheep during the various phases of the migrating myoelectric complex (MMC)

\begin{tabular}{|c|c|c|c|c|c|c|c|c|}
\hline & \multicolumn{4}{|c|}{$\begin{array}{c}\text { Cerulein 7.35 pmol/kg } \\
\text { MMC phase: }\end{array}$} & \multicolumn{4}{c|}{$\begin{array}{c}\text { Cerulein 73.5 pmol/kg } \\
\text { MMC phase: }\end{array}$} \\
\hline & 1 & $2 \mathrm{a}$ & $2 \mathrm{~b}(\mathrm{w})$ & $2 \mathrm{~b}(\mathrm{~s})$ & 1 & $2 \mathrm{a}$ & $2 \mathrm{~b}(\mathrm{w})$ & $2 \mathrm{~b}(\mathrm{~s})$ \\
\hline $30 \mathrm{~s}$ mean & - & 47 & 169 & 246 & 427 & 94 & 678 & 1168 \\
\pm S.D. & & 21 & 44 & 72 & 185 & 38 & 239 & 431 \\
\hline 60 s mean & - & 33 & 141 & 215 & 217 & 63 & 485 & 875 \\
\pm S.D. & & 17 & 48 & 49 & 108 & 27 & 181 & 318 \\
\hline 120 s mean & - & - & $27^{\mathrm{c}}$ & $68^{\mathrm{c}}$ & $86^{\mathrm{c}}$ & $39^{\mathrm{a}}$ & $146^{\mathrm{c}}$ & $211^{\mathrm{c}}$ \\
\pm S.D. & & & 11 & 25 & 33 & 16 & 65 & 87 \\
\hline 300 s mean & - & - & - & $45^{\mathrm{c}}$ & $55^{\mathrm{c}}$ & $24^{\mathrm{b}}$ & $64^{\mathrm{c}}$ & $84^{\mathrm{c}}$ \\
\pm S.D. & & & & 19 & 24 & 9 & 22 & 29 \\
\hline
\end{tabular}

Explanations: $2 \mathrm{~b}(\mathrm{w})$ - weak phase $2 \mathrm{~b}$ MMC; $2 \mathrm{~b}(\mathrm{~s})$ - strong phase $2 \mathrm{~b}$ MMC; $30 \mathrm{~s}, 60 \mathrm{~s}, 120 \mathrm{~s}, 300 \mathrm{~s}-$ the duration of hormone injections in seconds. Statistical significances vs. relevant $30 \mathrm{~s}$ value: ${ }^{\mathrm{a}} p<0.05,{ }^{\mathrm{b}} p<0.01,{ }^{\mathrm{c}} p<0.001$, $\mathrm{n}=6$, Student's $t$-test for paired values preceded by ANOVA I

Table 3. The durations of periods (in seconds) in which the antral slow wave amplitude was altered in response to the moderate and highest dose of CCK-OP, administered in non-fasted sheep during the various phases of the migrating myoelectric complex (MMC)

\begin{tabular}{|c|c|c|c|c|c|c|c|c|}
\hline & \multicolumn{4}{|c|}{$\begin{array}{l}\text { CCK-OP } 175 \mathrm{pmol} / \mathrm{kg} \\
\text { MMC phase: }\end{array}$} & \multicolumn{4}{|c|}{$\begin{array}{c}\text { CCK-OP } 1750 \mathrm{pmol} / \mathrm{kg} \\
\text { MMC phase: }\end{array}$} \\
\hline & 1 & $2 a$ & $2 b(w)$ & $2 \mathrm{~b}(\mathrm{~s})$ & 1 & $2 \mathrm{a}$ & $2 b(w)$ & $2 \mathrm{~b}(\mathrm{~s})$ \\
\hline 30 s mean & 343 & 143 & 208 & 259 & 327 & 78 & 266 & 378 \\
\hline \pm S.D. & 118 & 44 & 74 & 121 & 133 & 21 & 117 & 175 \\
\hline $60 \mathrm{~s}$ mean & $139^{\mathrm{b}}$ & $54^{\mathrm{b}}$ & 141 & 207 & $147^{\mathrm{a}}$ & 126 & 193 & 276 \\
\hline \pm S.D. & 58 & 26 & 62 & 84 & 63 & 54 & 86 & 127 \\
\hline $120 \mathrm{~s}$ mean & $54^{c}$ & $76^{\mathrm{a}}$ & $63^{c}$ & $46^{c}$ & $54^{c}$ & 52 & 122 & $108^{c}$ \\
\hline \pm S.D. & 23 & 41 & 24 & 41 & 24 & 41 & 39 & 43 \\
\hline $300 \mathrm{~s}$ mean & $36^{\mathrm{c}}$ & $18^{\mathrm{c}}$ & $31^{\mathrm{c}}$ & $23^{a}$ & $34^{\mathrm{c}}$ & - & $43^{\mathrm{c}}$ & $30^{c}$ \\
\hline \pm S.D. & 11 & 7 & 32 & 38 & 21 & & 17 & 24 \\
\hline
\end{tabular}

Explanations: $2 \mathrm{~b}(\mathrm{w})$ - weak phase $2 \mathrm{~b}$ MMC; $2 \mathrm{~b}(\mathrm{~s})$ - strong phase $2 \mathrm{~b}$ MMC; $30 \mathrm{~s}, 60 \mathrm{~s}, 120 \mathrm{~s}, 300 \mathrm{~s}-$ the duration of hormone injections in seconds. Statistical significances vs. relevant $30 \mathrm{~s}$ value: ${ }^{\mathrm{a}} p<0.05,{ }^{\mathrm{b}} p<0.01,{ }^{\mathrm{c}} p<0.001$, $\mathrm{n}=5$, Student's $t$-test for paired values preceded by ANOVA I

Table 4. The durations of periods (in seconds) in which the antral slow wave amplitude was altered in response to the moderate and high dose of cerulein, administered in non-fasted sheep during the various phases of the migrating myoelectric complex (MMC)

\begin{tabular}{|c|c|c|c|c|c|c|c|c|}
\hline & \multicolumn{4}{|c|}{$\begin{array}{c}\text { Cerulein 7.35 pmol/kg } \\
\text { MMC phase: }\end{array}$} & \multicolumn{4}{c|}{$\begin{array}{c}\text { Cerulein 73.5 pmol/kg } \\
\text { MMC phase: }\end{array}$} \\
\hline & 1 & $2 \mathrm{a}$ & $2 \mathrm{~b}(\mathrm{w})$ & $2 \mathrm{~b}(\mathrm{~s})$ & 1 & $2 \mathrm{a}$ & $2 \mathrm{~b}(\mathrm{w})$ & $2 \mathrm{~b}(\mathrm{~s})$ \\
\hline 30 s mean & 52 & - & - & - & 245 & 263 & 178 & 345 \\
\pm S.D. & 17 & & & & 94 & 107 & 123 & 118 \\
\hline 60 s mean & 30 & - & - & - & 202 & 194 & 126 & 266 \\
\pm S.D. & 8 & & & & 86 & 75 & 85 & 174 \\
\hline 120 s mean & - & - & - & - & $84^{\mathrm{b}}$ & $123^{\mathrm{a}}$ & 79 & $163^{\mathrm{a}}$ \\
\pm S.D. & & & & & 31 & 48 & 44 & 77 \\
\hline 300 s mean & - & - & - & - & $38^{\mathrm{c}}$ & $49^{\mathrm{c}}$ & 63 & $107^{\mathrm{c}}$ \\
\pm S.D. & & & & & 17 & 22 & 28 & 56 \\
\hline
\end{tabular}

Explanations: 2b (w) - weak phase 2b MMC; $2 \mathrm{~b}(\mathrm{~s})$ - strong phase $2 \mathrm{~b}$ MMC; $30 \mathrm{~s}, 60 \mathrm{~s}, 120 \mathrm{~s}, 300 \mathrm{~s}-$ the duration of hormone injections in seconds. Statistical significances vs. relevant $30 \mathrm{~s}$ value: ${ }^{\mathrm{a}} p<0.05,{ }^{b} p<0.01,{ }^{\mathrm{c}} p<0.001$, $\mathrm{n}=6$, Student's $t$-test for paired values preceded by ANOVA I 

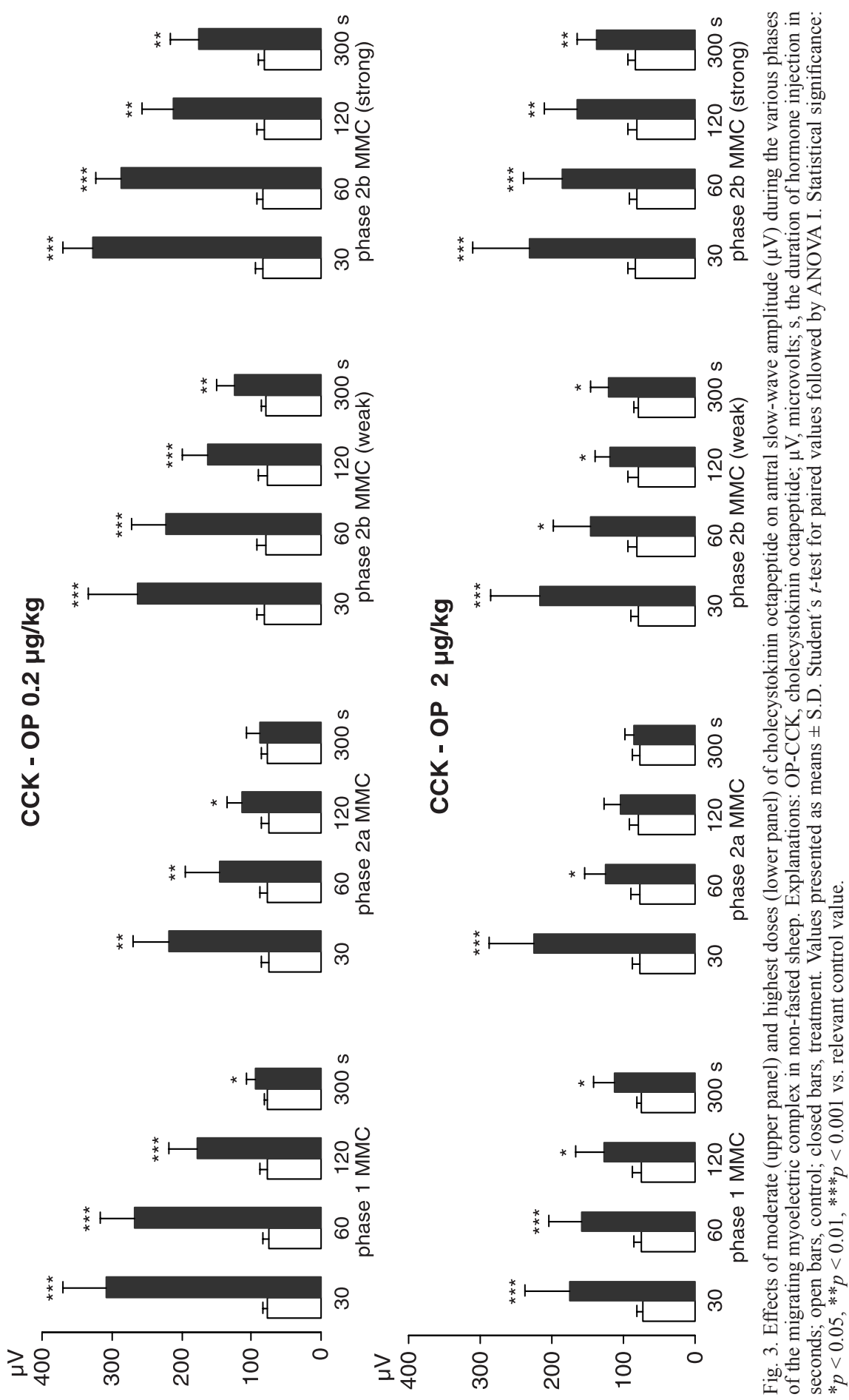

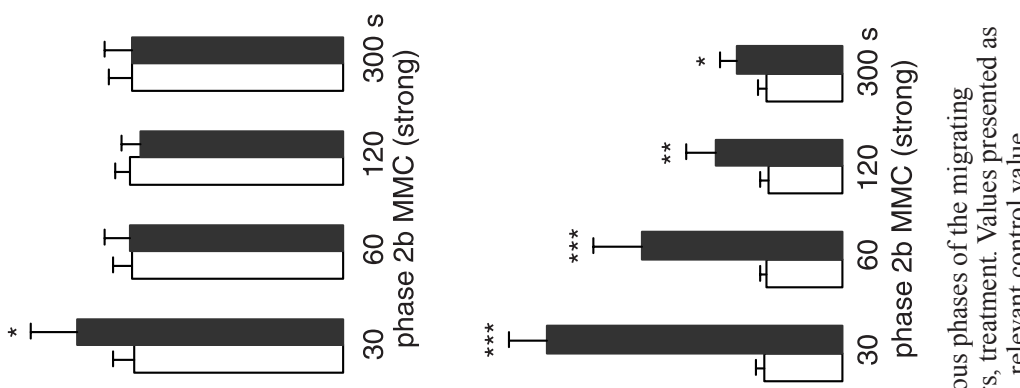

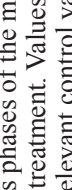

햏ํㄹ

$>$ 훙
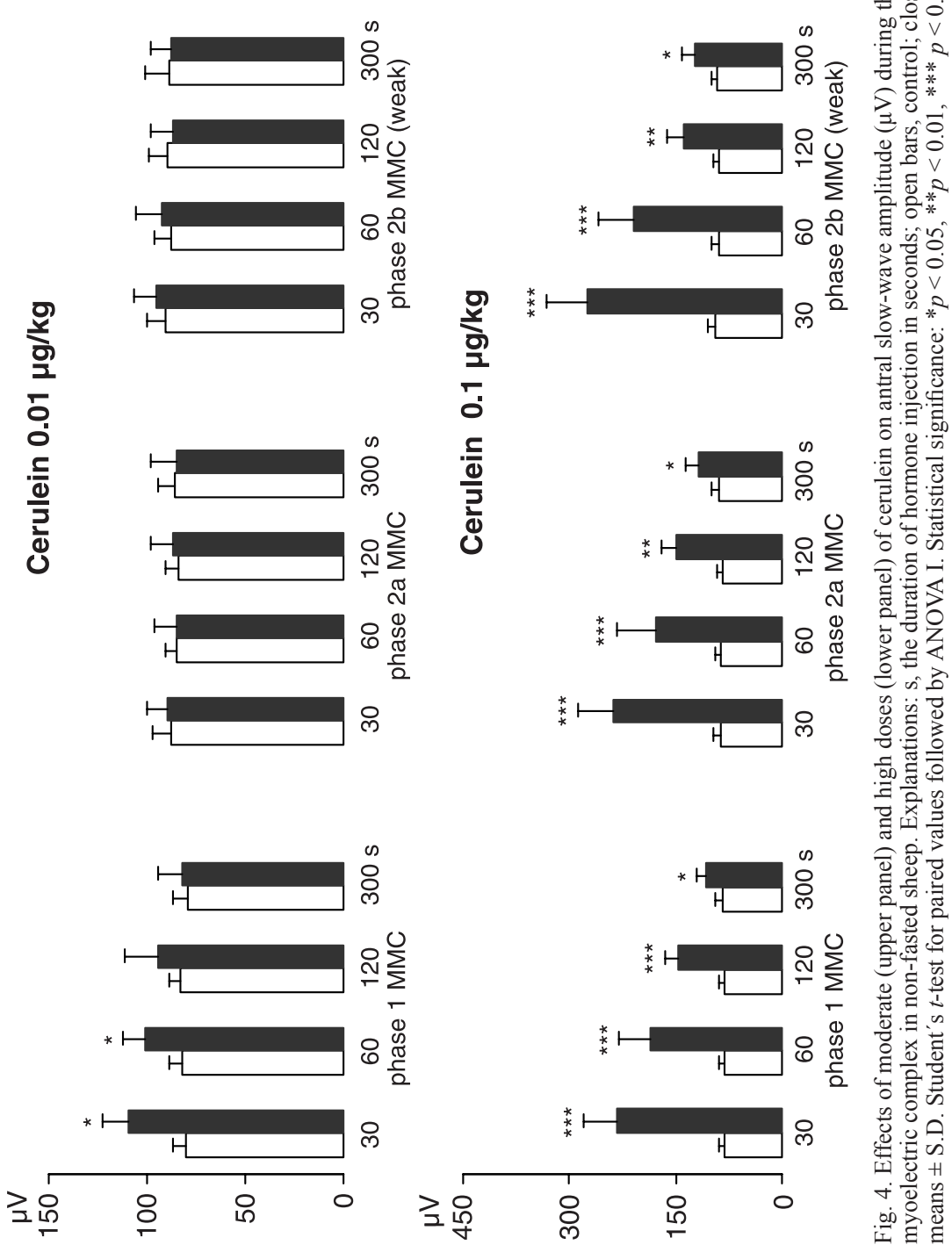
the effect of the highest dose (Fig. 3). The differences between the doses of CCK-OP given for 30,60 , or 120 min were not marked. The effect of the hormone on slow-wave amplitude was monophasic and was most evident when the CCK peptide was given during phase $2 \mathrm{~b}$ or phase 1 of the MMC (Fig. 3). The duration of increased slow-wave amplitude was also prolonged. The duration of these changes was longest when CCK-OP was administered for
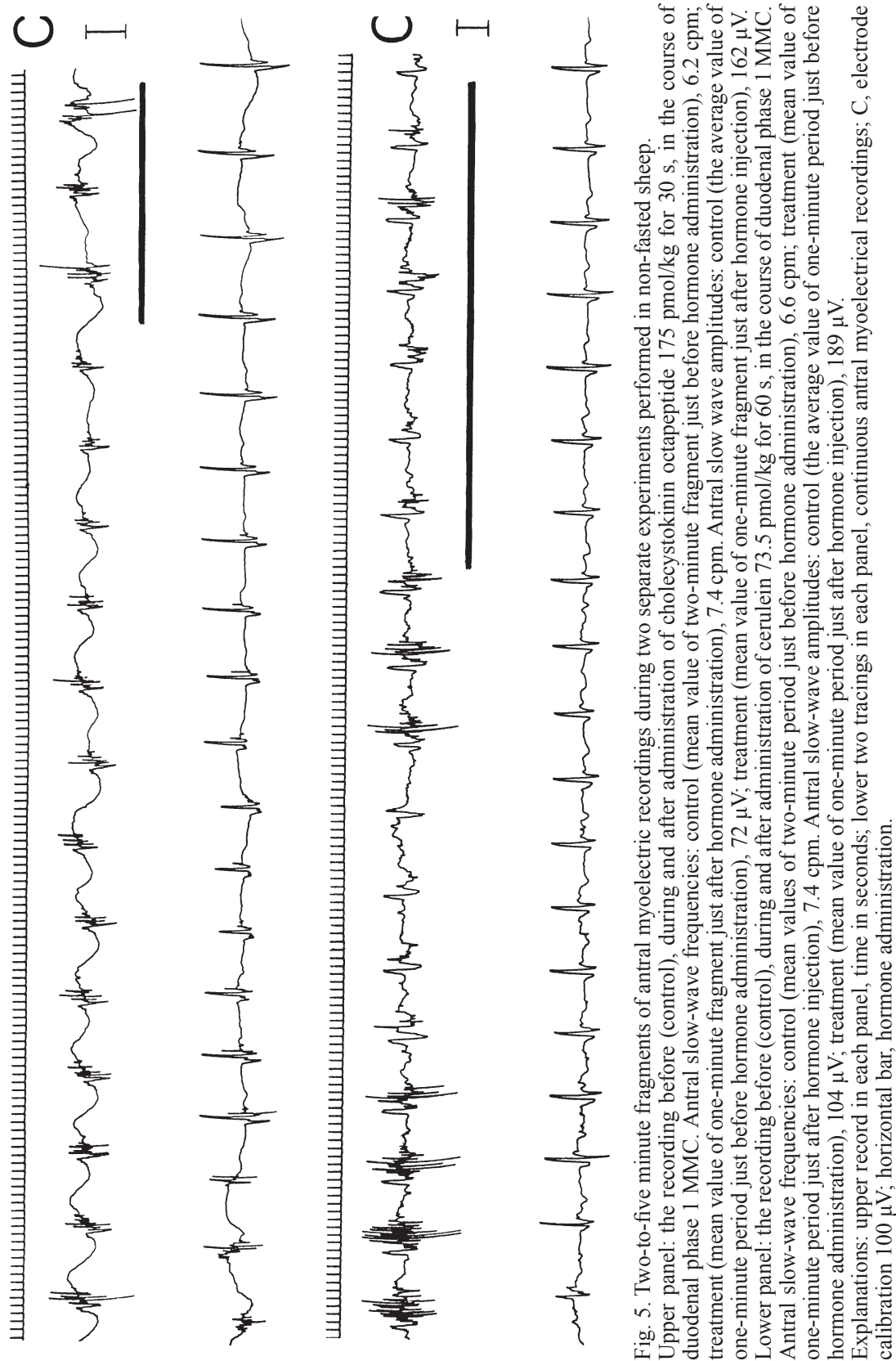
$30 \mathrm{~s}$ or when the hormone was given during phase $2 \mathrm{~b}$ of the MMC (Table 3). This effect was thus of a dose-response type.

Comparison of the effects of CCK-OP and cerulein on the antral slow-wave amplitude and frequency in non-fasted sheep

The increase in slow-wave amplitude following cerulein administration was usually smaller than after CCK-OP, but the differences between the moderate and highest dose of the hormone were much greater (Fig. 4). In some cases, the effect of the hormone administered during phase 1 was more pronounced than the effect of the given dose of the hormone administered during phase $2 \mathrm{~b}$ of the MMC. However, the effect of cerulein administered for $300 \mathrm{~s}$, even at the highest dose, was the smallest. The duration of these changes was usually significant and was related to the hormonal peptide dose and MMC phase (Table 4). The duration of changes in slow-wave amplitude was shortest when the duration of cerulein administration was $300 \mathrm{~s}$. The effect of the moderate dose of CCK-OP on the antral slow-wave frequency and amplitude was often not much different from the effect of the high dose of cerulein (Fig. 5).

Effects of CCK peptides on the antral slow-wave frequency and amplitude in fasted sheep. There were no marked differences in the antral myoelectric response to CCK peptides between fasted and non-fasted sheep although the changes in antral slow-wave frequency and amplitude were slightly less evident in fasted sheep. These results are therefore not shown.

\section{Discussion}

Both CCK peptides given in moderate and higher doses significantly affected the ovine antral slow-wave frequency and amplitude and the response was usually biphasic. The increase in slow-wave frequency from about $6-7 \mathrm{cpm}$ to about $8 \mathrm{cpm}$ cannot be interpreted as a tachygastria-evoking effect despite the preservation of the regular rhythm of the slow waves. During tachygastria, the increase in antral slow-wave frequency in monogastrics is much higher (Kohagen et al. 1996). Furthermore, tachygastria has never been described in sheep. It is known that during inhibition of spike activity, the antral slow-wave frequency can increase slightly, but in sheep these changes usually oscillate within $5.5-7 \mathrm{cpm}$ (Romański 2002). The evident modulatory action of CCK peptides on antral slow waves can occur when CCK receptors are present on the gastric cells generating the slow waves. It has recently been demonstrated that CCK receptors are present on the interstitial cells of Cajal (Patterson et al. 2001). These cells have never been found in sheep, but it is rather obvious that they occur also in this species.

There are some reports suggesting that CCK can increase the slow-wave frequency in various animal species, including dogs and cats (Ohkawa and Watanabe 1977; Thomas et al. 1979). A preliminary study also showed that a similar effect could be observed in sheep (Romański 2004a). Other reports present opposite results (Chen et al. 1995; Wingate et al. 1978) and are contrary to the presented results. Several reasons for this discrepancy should be taken into account. CCK's action is mediated by at least two distinct receptor subtypes, i.e. the CCK-1 (CCK-A) receptor subtype and the CCK-2 (CCK-B/gastrin) receptor subtype. CCK, as a circulating hormone, can reach the target organ in different ways, including along an endocrine and probably a paracrine pathway, and it has long been thought that CCK is also a neuromodulator and can exert its effects via a neurocrine (most probably with brain involvement) or neuroendocrine mechanism (Miyasaka and Funakoshi 2003; Reidelberger et al. 2003; Dockray 2006). Furthermore, CCK can affect the release of other hormones, thus potentiating their effects (Zavros et al. 1998). In principle it can be expected that CCK-OP administered intravenously can act peripherally, since CCK-OP does not cross the blood- 
brain barrier. In spite of this, a central action of at least other forms of CCK or cerulein after intravenous administration cannot be excluded (Fioramonti and Bueno 1988). Thus it is also possible that the myogenic control of gastrointestinal motility comprises central and peripheral components which can produce a biphasic response. It is also possible that this post-stimulatory effect was evoked by increased release of somatostain in response to CCK administration (Zavros and Shulkes 1997).

There are no data available regarding the effect of CCK on the slow-wave amplitude and it appears that the effect on the slow-wave frequency is more important physiologically than the effect upon the slow-wave amplitude. It is well known that slow waves do not induce contractions unless they exceed the mechanical threshold, and in the terminal antrum slow waves can contribute to phasic contractions (Szurszewski 1987). Therefore the increase in slow-wave amplitude can stimulate or facilitate the occurrence of mechanical events, but to a limited extent. CCK is one of the relatively few hormonal regulators affecting slow waves and the most common neural receptor blockers have little or no effect on their frequency or amplitude (Sanders and Publicover 1989). CCK is a physiological regulator of gastric function, at least when gastric emptying is considered (Grider 1994; Reidelberger et al. 2001). However, the response to the highest doses of CCK peptides used in this study seems to be pharmacological, at least in part. There are no precise data in sheep indicating what doses can still be considered physiological. Zavros and Shulkes (1997) showed that in 12-18 h fasted sheep a 45-min infusion of CCK-OP at a rate of 150 $\mathrm{pmol} / \mathrm{kg} / \mathrm{h}$ caused stabilization of the plasma CCK level at $34 \pm 7 \mathrm{pmol} / \mathrm{l}$, i.e. almost six times above the basal level. However, the postprandial plasma concentration of CCK in sheep can be higher and, considering the relatively high metabolic clearance rate, it can be assumed that this dose could be supraphysiological rather than pharmacological. In calves, a CCK dose of $30 \mathrm{pmol} / \mathrm{kg} / \mathrm{min}$ infused during $40 \mathrm{~min}$ stimulating pancreatic secretion was physiological (Le Drean et al. 1999). In humans $40 \mathrm{ng} / \mathrm{kg} / \mathrm{h}$ of CCK-OP was suggested to be a supraphysiological dose and $10 \mathrm{ng} / \mathrm{kg} / \mathrm{h}$ a physiological dose (Soudah et al. 1992). In dogs, CCK-OP infusion at a rate of $125 \mathrm{ng} / \mathrm{kg} / \mathrm{h}$ inhibited gastric emptying and this dose was also considered physiological (Debas et al. 1975). Thus it seems likely that most of the doses of CCK peptides used in this study are physiological. The highest dose used here may be supraphysiological as well.

The present results indicate that CCK-OP given at over 20-times higher doses than those of cerulein evoked a stronger effect on antral slow waves in sheep. However when the same dose of CCK peptides was infused, cerulein evoked stronger effects than CCK-OP, which suggests its greater affinity to CCK receptors.

The considerably small differences in the effects of CCK peptides on antral slow waves between fasted and non-fasted sheep can be explained by the species-specific function of the gastrointestinal tract. Even in two-day fasted ruminants, the rumen is not empty; thus the digesta flow from the rumen to the duodenum continues. Therefore there are relatively small differences in duodenal hormone release and neural stimulation by the flow of digesta between fasted and non-fasted animals.

Finally, it can be concluded that cholecystokinin can alter slow-wave frequency and amplitude in the ovine pyloric antrum and these effects are often biphasic. This suggests a direct influence of the hormone on the interstitial cells of Cajal.

\section{Vliv různých dávek oktapeptidu cholecystokininu a ceruleinu na snížení frekvence a amplitudy pomalé antrální peristaltické vlny u ovce domácí}

Existuje obecný předpoklad, že cholecystokinin (CCK) je schopen snížit frekvenci a rozsah peristaltických vln, ale tato problematika nebyla dosud u ovce domácí prostudována. Proto byl pořízen kontinuální záznam myoelektrické aktivity před a po intravenózní aplikaci $0.15 \mathrm{M} \mathrm{NaCl}$ nebo peptidu $\mathrm{CCK}$ u dospělých beranů s implantovanými bipolárními plati- 
novými elektrodami v abomasální dutině, duodenu a jejunu. Pěti beranům byl podán CCK oktapeptid (CCK-OP) v dávkách 17.5, 175, nebo 1750 pmol/kg a šesti beranům byl aplikován cerulein $\mathrm{v}$ dávkách $0.735,7.35$, nebo $73.5 \mathrm{pmol} / \mathrm{kg}$ tělesné hmotnosti. Jednotlivé dávky těchto látek byly podávány v infuzi lačnícím nebo krmeným zvířatům po dobu 30, 60, 120, nebo $300 \mathrm{~s}$ během více či méně intenzivní fáze 1 , 2a nebo $2 \mathrm{~b}$ migrujícího myoelektrického komplexu (MMC). Infuze obsahující střední dávky CCK-OP podávaná po dobu $300 \mathrm{~s}$ během nízké nebo vysoké intenzity fáze $2 \mathrm{~b} M \mathrm{MMC}$ měla za následek vzrůst amplitudy pomalé antrální peristaltické vlny z $79 \pm 7$ na $124 \pm 26 \mu \mathrm{V}(p<0.01)$ resp. z $82 \pm 8$ na $175 \pm 40 \mu \mathrm{V}$ $(p<0.001)$. Aplikace nejvyšší dávky CCK-OP po dobu 300s za stejných podmínek zvýšil amplitudu pomalé antrální peristaltické vlny z $79 \pm 6$ na $121 \pm 24 \mu \mathrm{V}(p<0.05)$ a z $84 \pm 9$ na $138 \pm 27 \mu \mathrm{V}(p<0.01)$. Po podání střední dávky CCK po dobu $120 \mathrm{~s}$ během $2 \mathrm{~b}$ fáze MMC vzrostla frekvence pomalé antrální peristaltické vlny z $6.1 \pm 0.2$ na $6.6 \pm 0.4 \mathrm{cpm}$ (N.S.) během vysoké intenzity $2 \mathrm{~b}$ a z $6.1 \pm 0.3$ na $6.8 \pm 0.4 \mathrm{cpm}(p<0.05)$ během nízké intenzity $2 \mathrm{~b}$.

Infuze s obsahem nejvyšší dávky CCK-OP po dobu $120 \mathrm{~s}$ během vysoké nebo nízké intenzity fáze $2 \mathrm{~b}$ MMC zvýšila frekvenci pomalé antrální peristaltické vlny z $6.2 \pm 0.3$ na $7.2 \pm 0.4(p<0.05)$ respektive z $6.0 \pm 0.3$ na $7.8 \pm 0.6 \mathrm{cpm}(p<0.001)$. Tato studie tedy potvrzuje, že CCK ve fyziologických nebo v uvedených farmakologických dávkách působí na frekvenci i rozsah pomalých antrálních peristaltických vln u ovce domácí částečně související s fází MMC tenkého střeva a intenzitou antrální motorické aktivity.

\section{References}

CHEN JD, LIN ZY, PAROLISI S, McCALLUM RW 1995: Inhibitory effects of cholecystokinin on postprandial gastric myoelectrical activity. Dig Dis Sci 40: 2614-2622

CODE CF, MARLETT JA 1975: The interdigestive myoelectric complex of the stomach and small bowel of dogs. J Physiol (Lond) 246: 289-309

DEBAS HT, FAROOQ O, GROSSMAN MI 1975: Inhibition of gastric emptying is a physiological action of cholecystokinin. Gastroenterology 68: 1211-1217

DENT J, DODDS WJ, SEKIGUCHI T, HOGAN WJ, ARNDORFER RC 1983: Interdigestive phasic contractions of the human lower esophageal sphincter. Gastroenterology 84: 453-460

DOCKRAY GJ 2006: Gastrointestinal hormones: gastrin, cholecystokinin, somatostatin, and ghrelin. In: JOHNSON LR, BARRETT KE: Physiology of the gastrointestinal tract. Elsevier Academic Press, Amsterdam, pp. 91-120

FIORAMONTI J, BUENO L 1988: Hormonal control of gut motility in ruminants and non-ruminants and its nutritional implications. Nutr Res Rev 1: 169-188

GRIDER JR 1994: Role of cholecystokinin in the regulation of gastrointestinal motility. J Nutr 124: 1334S-1339S

KOHAGEN KR, KIM MS, McDONNELL WM, CHEY WD, OWYANG C, HASLER WL 1996: Nicotine effects on prostaglandin-dependent gastric slow wave rhythmicity and antral motility in nonsmokers and smokers. Gastroenterology 110: 3-11

KUWAHARA A, OZAWA K, YANAIHARA N 1986: Effects of cholecystokinin-octapeptide on gastric motility of anesthetized dogs. Am J Physiol-Gastrointest Liver Physiol 251: G678-G681

LE DREAN G, LE HUEROU-LURON I, GESTIN M, DESBOIS C, ROME V, BERNARD C, DUFRESNE M, MORODER L, GULLY D, CHAYVIALLE JA, FOURMY D, GUILLOTEAU P 1999: Exogenous CCK and gastrin stimulate pancreatic exocrine secretion via CCK-A but also via CCK-B/gastrin receptors in the calf. Pflügers Arch 438: 86-93

McLEAY LM, BELL FR 1980: Effect of cholecystokinin, secretin, glucagon, and insulin on gastric emptying and acid secretion in the calf. Am J Vet Res 41: 1590-1594

MIYASAKA K, FUNAKOSHI A 2003: Cholecystokinin and cholecystokinin receptors. J Gastroenterol 38 : $1-13$

MORGAN KG, SCHMALZ PF, GO VL, SZURSZEWSKI JH 1978: Electrical and mechanical effects of molecular variants of CCK on antral smooth muscle. Am J Physiol-Endocrinol Metab 235: E324-E329

NOBLE F, WANK SA, CRAWLEY JN, BRADWEJN J, SEROOGY KB, HAMON M, ROQUES BP 1999: International Union of Pharmacology. XXI. Structure, distribution, and functions of cholecystokinin receptors. Pharmacol Rev 51: 745-781

OGAWA Y, TANAKA M 1992: Biliary pressure variation in coordination with migrating motor complex of duodenum in patients with cholecystectomy and effects of morphine and cerulein. Dig Dis Sci 37: 1531-1536

OHKAWA H, WATANABE M 1977: Effects of gastrointestinal hormones on the electrical and mechanical activity of the cat stomach. Tohoku J Exp Med 122: 287-298 
PATTERSON LM, ZHENG H, WARD SM, BERTHOUD HR 2001: Immunochemical identification of cholecystokinin A receptors on interstitial cells of Cajal, smooth muscle, and enteric neurons in rat pylorus. Cell Tissue Res 305: 11-23

REIDELBERGER RD, ARNELO U, GRANQVIST L, PERMERT J 2001: Comparative effects of amylin and cholecystokinin on food intake and gastric emptying in rats. Am J Physiol-Regul Integr Comp Physiol 280: R605-R611

REIDELBERGER RD, KELSEY L, HEIMANN D, HULCE M 2003: Effects of peripheral CCK receptor blockade on gastric emptying in rats. Am J Physiol-Regul Integr Comp Physiol 284: R66-R75

ROMAŃSKI KW 2002: Influence of various feeding conditions, the migrating myoelectric complex and cholinergic drugs on antral slow waves in sheep. Arch Tierernahr 56: 393-408

ROMAŃSKI KW 2004a: Ovine model for clear-cut study on the role of cholecystokinin antral, small intestinal and gallbladder motility. Pol J Pharmacol 56: 247-256

ROMAŃSKI KW 2004b: Feeding versus cholecystokinin - spectrum of actions on ovine gallbladder contractility assessed with real-time ultrasonography. Wien Tierarztl Monatsschr 91: 226-235

ROMAŃSKI KW 2005: The role of muscarinic and nicotinic receptors in the control of the ovine pyloric antral myoelectric response to nutrients during individual phases of the migrating myoelectric complex. Small Ruminant Res 57: 121-131

RUCKEBUSCH Y 1988: Motility of the gastrointestinal tract. In: CHURCH DC: The ruminant animal. Digestive physiology and nutrition. A Reston Book, Prentice Hall, Englewood Cliffs, pp. 64-107

SANDERS KM, PUBLICOVER NG 1989: Electrophysiology of the gastric musculature, In: SCHULTZ SG (Section editor): Handbook of physiology. The gastrointestinal system. American Physiological Society, Bethesda, Maryland pp. 187-216

SCARPIGNATO C, VARGA G, CORRADI C 1993: Effect of CCK and its antagonists on gastric emptying. J Physiol (Paris) 87: 291-300

SNEDECOR GW, COCHRAN WG 1971: Statistical Methods. The Iowa State University Press, Ames, Iowa, $575 \mathrm{p}$.

SOUDAH HC, LUY, HASLER WL, OWYANG C 1992: Cholecystokinin at physiological levels evokes pancreatic enzyme secretion via a cholinergic pathway. Am J Physiol-Gastrointest Liver Physiol 263: G102-G107

STACHER G, STEINRINGER H, SCHMIERER G, SCHNEIDER C, WINKLEHNER S, MITTELBACH G, DE PAOLIS C, PRAGA C 1984: Dose-dependent effects of ceruletide on jejunal motor activity and on experimentally induced pain in healthy humans. In: ROMAN C (Ed.): Gastrointestinal Motility, MTP Press Limited, Lancaster, pp. 355-356

SZURSZEWSKI JH 1987: Electrical basis for gastrointestinal motility. $2^{\text {nd }}$ ed. In: JOHNSON LR (Ed.): Physiology of the Gastrointestinal Tract. Raven Press, New York, pp. 383-422

TACHIBANA S, ONAGA T, MINEO H, KATO S 1995: Role of endogenous CCK in regulation of interdigestive pancreatic endocrine secretion in sheep. Comp Biochem Physiol A 112: 103-109

THOMAS PA, AKWARI OE, KELLY KA 1979: Hormonal control of gastrointestinal motility. World J Surg 3 : 545-552

THOR P, LASKIEWICZ J, KONTUREK P, KONTUREK SJ 1988: Cholecystokinin in the regulation of intestinal motility and pancreatic secretion in dogs. Am J Physiol-Gastrointest Liver Physiol 255: G498-G504

TITCHEN DA 1986: Gastrointestinal peptide hormone distribution, release, and action in ruminants. In: MILLIGAN LP, GROVUM WL, DOBSON A (Eds): Control of digestion and metabolism in ruminants. A Reston Book, Prentice Hall, Englewood Cliffs, pp. 227-248

WINGATE DL, PEARCE EA, HUTTON M, DAND A, THOMPSON HH, WÜNSCH E 1978: Quantitative comparison of the effects of cholecystokinin, secretin, and pentagastrin on gastrointestinal myoelectric activity in the conscious fasted dog. Gut 19: 593-601

ZAVROS Y, FLEMING WR, HARDY KJ, SHULKES A 1998: Regulation of fundic antral somatostatin secretion by CCK and gastrin. Am J Physiol-Gastrointest Liver Physiol 274: G742-G750

ZAVROS Y, SHULKES A 1997: Cholecystokinin (CCK) regulates somatostatin secretion through both the CCK-A and CCK-B/gastrin receptors in sheep. J Physiol (Lond), 505: 811-821 
